\title{
Cellular and biochemical responses of the oyster Crassostrea gigas to controlled exposures to metals and Alexandrium minutum
}

\author{
Hansy Haberkorn ${ }^{\mathrm{a}}$, Christophe Lambert ${ }^{\mathrm{a}}$, Nelly Le Goïc ${ }^{\mathrm{a}}$, Claudie Quéré ${ }^{\mathrm{b}}$, Audrey Bruneau ${ }^{\mathrm{a}}$, \\ Ricardo Riso ${ }^{a}$, Michel Auffret $^{a}$, Philippe Soudant ${ }^{a, *}$
}

\begin{abstract}
a Laboratoire des Sciences de l'Environnement Marin, UMR 6539, Institut Universitaire Européen de la Mer, Université de Bretagne Occidentale, Place Copernic, Technopôle Brest-Iroise, 29280 Plouzané, France

b IFREMER Centre de Brest, Laboratoire de Physiologie des Invertébrés, Unité Physiologie Fonctionnelle des Organismes Marins, BP 70, 29280 Plouzané, France
\end{abstract}

\author{
*: Corresponding author: Philippe Soudant, tel.: +33 298498623 ; fax: +33298498645 ; \\ email address : Philippe.Soudant@univ-brest.fr
}

\begin{abstract}
:
Effects of simultaneous exposure of Pacific oyster, Crassostrea gigas, to both a harmful dinoflagellate that produces Paralytic Shellfish Toxins (PST), Alexandrium minutum, and cadmium (Cd) and copper (Cu), were assessed. Oysters were exposed to a mix of $\mathrm{Cd}-\mathrm{Cu}$ with two different diets (i.e. A. minutum or Tisochrysis lutea) and compared to control oysters fed $A$. minutum or $T$. lutea, respectively, without metal addition. Metals and PST accumulations, digestive gland lipid composition, and cellular and biochemical hemolymph variables were measured after 4 days of exposure. Oysters exposed to $\mathrm{Cd}-\mathrm{Cu}$ accumulated about thirty-six times less PSTs than oysters exposed to A. minutum alone. Exposure to $\mathrm{Cd}-\mathrm{Cu}$ induced significant changes in neutral lipids (increase in diacylglycerol DAG - and decrease in sterols) and phospholipids (decreases in phosphatidylcholine, phosphatidylethanolamine, cardiolipin and ceramide aminoethylphosphonate) of digestive gland suggesting that lipid metabolism disruptions and/or lipid peroxidation have occurred. Simultaneously, concentrations, percentages of dead cells and phenoloxidase activity of hemocytes increased in oysters exposed to metals while reactive oxygen species production of hemocytes decreased. Feeding on the harmful dinoflagellate A. minutum resulted in significant decreases in monoacylglycerol (MAG) and DAG and ether glycerides (EG), as well as significant increases in hemocyte concentration and phagocytic activity as compared to oysters fed $T$. lutea. Finally, the present study revealed that short-term, simultaneous exposure to $\mathrm{Cd}-\mathrm{Cu}$ and $A$. minutum may induce antagonistic (i.e. hemocyte concentration and phagocytosis) or synergic (i.e. DAG content in digestive gland) effects upon cellular and tissular functions in oysters.
\end{abstract}

\section{Highlights}

Oysters, C. gigas, were exposed to both metals and PST-producer A. minutum. Oysters exposed to metals accumulated about thirty-six times less PSTs. Exposure to both metals and $A$. minutum induced antagonistic or synergetic effects.

Keywords: Harmful algae ; Metals ; Oysters ; Toxin accumulation ;Physiological effects 


\section{Introduction}

In the natural environment, aquatic organisms, such as bivalves, experience numerous natural and/or anthropogenic stressors. In aquatic mollusks, interactions between different stressors, such as infectious diseases and pollution, have received increasing attention over recent years (Morley, 2010). Among pollutants, metals, often of anthropogenic origin, are known to have important effects upon fauna and flora in littoral ecosystems (Morley, 2010). Harmful microalgal blooms are another recognized biological stressor which can have important effects upon aquatic organisms and ecosystems (Landsberg, 2002).

Among HAB taxa, Alexandrium species are not only known to produce Paralytic Shellfish Toxins (PSTs), the most widespread shellfish-contaminating biotoxins with outbreaks occurring worldwide, but also to modify bivalve biology at different levels of organization (Huss, 2003, Hégaret et al., 2007a; Galimany et al., 2008a, b and c; Haberkorn, 2009; Haberkorn et al., 2010a and b). In France, Alexandrium minutum has been known to bloom in coastal waters since the 1980s (Lassus et al., 1992). PSTs produced by these blooms are neurotoxins, the mode of action of which involves a reversible and highly-specific block of sodium channel transport, disabling the action potential of excitable membranes (nerves and muscle fibers) (Narahashi, 1988). The current European Union regulatory limit for human consumption of shellfish is set at $80 \mu \mathrm{g}$ saxitoxin equivalent $100 \mathrm{~g}^{-1}$ shellfish meat.

Alexandrium species also are known to produce other toxic compounds, such as ichthyotoxins (Emura et al., 2004) and allelochemicals (Arzul et al., 1999; Tillmann et al., 2008; Lelong et al., 2011). Ford et al. (2008) assessed effects of two A. tamarense strains, PST and non-PST producing, upon Manila clam Ruditapes philippinarum and Mya arenaria hemocytes. This study showed that the non-PST strain had more negative effects upon hemocytes (decreased adhesion and phagocytosis) compared to the PST-producing strain of A. tamarense (Ford et al., 2008).

Metals also have negative effects upon bivalve physiology, including hemocyte variables and the digestive system (Zorita et al., 2006; Gagné et al., 2008; Paul-Pont et al., 2010). Metal ions can bind with organic molecules and induce reactive oxygen species formation leading to oxidative damage (Dorsey et al., 2004; Faroon et al., 2012). In France, shellfish contamination with cadmium $(\mathrm{Cd})$ and copper $(\mathrm{Cu})$ is reported regularly near the main estuaries (Gironde and Seine estuaries, ROCCH/RNO-IFREMER). Cadmium (Cd) is a toxic 
and non-essential metal with an extremely long biological half-life, making it a cumulative toxic compound. It has been classified as a human carcinogen and is a potent multi-tissue animal carcinogen (IARC, 1993). Most bivalve mollusks are filter feeders and concentrate Cd and other metals in their soft tissues (Bouilly et al., 2006). This accumulated Cd can compromise the health of consumers of contaminated bivalves. The allowable Cd limits in seafood vary between $1 \mu \mathrm{g} \mathrm{g}^{-1}$ wet weight (European Union) and $3.7 \mu \mathrm{g} \mathrm{g}^{-1} \mathrm{WW}$ (USA, United States Food and Drug Administration recommended guideline) (Lekhi et al., 2008). The Provisional Tolerable Daily Intake (PTDI) recommended by the World Health Organization (WHO) for human oral exposure is $7 \mu \mathrm{g} \mathrm{kg}^{-1} \mathrm{day}^{-1}$ (WHO, 2006). Copper (Cu) is an essential metal for all marine organisms, but it can be toxic at elevated concentrations (Parry and Pipe, 2004). The Tolerable Daily Intake (TDI) recommended by the Dutch National Institute for Public Health and the Environment (Rijksinstituut voor volksgezondheid en milieu - RIVM) for human oral exposure is $140 \mathrm{\mu g} \mathrm{kg}^{-1}$ day $^{-1}$ (Baars et al., 2001). In comparison, the TDI recommended for Cd by RIVM for human oral exposure is $5 \mu \mathrm{gg}^{-1}$ day $^{-1}$ (Baars et al., 2001).

In bivalves, the digestive system appears to be a revelant target to evaluate interactions of toxic compounds such as phycotoxins and metals. Harmful microalgae were recently shown to interfere with the digestive system of bivalves. Degeneration of the digestive gland (digestive ducts and tubules) was observed in the mussel, Mytilus edulis, exposed to Alexandrium fundyense (Galimany et al., 2008a). In Pacific oysters, Crassostrea gigas, exposed to A. minutum, lipid composition of the digestive gland was altered drastically, mainly in terms of phospholipid composition (Haberkorn et al., 2010b). The digestive gland is known to accumulate most of the $\mathrm{Cd}$ and $\mathrm{Cu}$ in naturally-exposed C. gigas from Gironde estuary (Mouneyrac et al., 1998). Metals also appear to have profound effects upon the digestive systems of bivalves. For example, lipid peroxidation was observed in the digestive gland of the blue mussel, M. edulis, exposed to Cd - $200 \mu \mathrm{g}^{-1}$ for 21 days (Géret et al., 2002). Similarly, Ringwood et al. (1998) reported lipid peroxidation in C. virginica exposed to $\mathrm{Cu}-80 \mu \mathrm{g} \mathrm{l} \mathrm{l}^{-1}$ for 14 days. Moreover, the digestive gland represents the major site of metal accumulation in bivalves (Pipe et al., 1999) as is also the case for PSTs (Bricelj and Shumway, 1998).

In addition to affecting the digestive system, both phycotoxins and metals are known to affect activities of circulating cells (i.e. hemocytes) involved in bivalve immunity and general homeostasis (Donaghy et al., 2009). Recent studies demonstrated immunomodulation in 
109 bivalves induced by harmful microalgae (Hégaret et al., 2007a; Galimany et al., 2008b and c;

110 Haberkorn et al., 2010a) and metals (Cherkasov et al., 2007; Dailianis, 2009; Morley, 2010).

111 Inflammatory responses, characterized by diapedesis of hemocytes within tissues, were

112 observed in M. edulis exposed to Prorocentrum minimum and to Karlodinium veneficum

113 (Galimany et al., 2008b and c) and in C. gigas exposed to A. minutum (Haberkorn et al.,

114 2010b). Moreover, changes in hemocyte morphology and/or functions (such as phagocytosis,

115 reactive oxygen species production, phenoloxidase activity) were observed in C. gigas

116 exposed to A. minutum (Haberkorn et al., 2010b), in C. gigas and C. virginica exposed to A.

117 catenella and A. fundyense (Hégaret et al., 2007a), and in M. edulis exposed to A. fundyense,

118 P. minimum, and K. veneficum (Galimany et al., 2008a, b and c). In vitro exposure of

119 hemocytes of the oyster, $C$. virginica, to $\mathrm{Cd}-50$ to $1,000 \mu \mathrm{mol}^{-1}$ for 3 days- induced

120 increases in apoptosis in a concentration-dependent manner (Sokolova et al., 2004). Increase

121 in hemocyte apoptosis also was observed during in vivo exposure of $C$. virginica hemocytes

122 to $\mathrm{Cd}-50 \mu \mathrm{g} \mathrm{l}^{-1}$ for 45 days - (Cherkasov et al., 2007). Increase in reactive oxygen species

123 (ROS) production was observed during in vitro exposure to $\mathrm{Cd}-0.05$ to $500 \mu \mathrm{mol} \mathrm{l}^{-1}$ for $1 \mathrm{~h}$

124 - of hemocytes of mussels, M. galloprovincialis (Dailianis, 2009). In flat oysters, in vivo

125 exposure to a Cd and Cu mixture -1 to $10 \mu \mathrm{mol} \mathrm{l}^{-1}$ and $0.75 \mu \mathrm{mol} \mathrm{l}^{-1}$, respectively, for 7 days

126 - Auffret et al. (2002) caused concentration-dependent increases in total hemocyte count and

127 ROS production by hemocytes, suggesting a toxic stimulation of the immune system.

128

129 As in the field stressors rarely act individually, multiple-stress studies are now emerging. Few

130 studies have investigated potential simultaneous effects of pollutants and biological stressors

131 (such as metals/bacteria, metals/macroparasites, macroparasites/harmful microalgae or

132 metals/macroparasites/bacteria) on defense-related activities of bivalves such as detoxification

133 processes, endocrine system, and hemocyte responses (Pipe and Coles, 1995; Baudrimont and

134 de Montaudouin, 2007; Hégaret et al., 2007b; Da Silva et al., 2008; Paul-Pont et al., 2010).

135 Interactive effects of infectious diseases and pollution in aquatic mollusks were reviewed by

136 Morley (2010). To the best of our knowledge, no study has evaluated combined effects of

137 both metals and harmful microalgae upon bivalves.

138

139 The purpose of the present study was to explore possible combined effects of an artificial

140 bloom of the PST-producing dinoflagellate, A. minutum (strain AM89BM), and a mixture of

141 two metals, cadmium and copper (Cd-Cu) on the Pacific oyster C. gigas. Oysters were

142 exposed 4 days to i) Tisochrysis lutea (formerly Isochrysis sp., clone Tahitian) as a control, ii) 
143 A. minutum alone, iii) T. lutea + Cd-Cu, and iv) A. minutum + Cd-Cu. After exposure, toxin

144 and metal accumulations, lipid class composition, and amylase activity in digestive gland, as

145 well as concentration, morphology, viability, phagocytic activity, reactive oxygen species

146 production of hemocytes, and phenoloxidase activity (in plasma and hemocytes), were

147 measured.

148

149 


\section{Materials and methods}

$150 \quad 2.1$ Biological material

$151 \quad 2.1 .1$ Oysters

152 Pacific oysters, Crassostrea gigas, used in the experiment were obtained from an oyster

153 producer at île de Kerner (Morbihan, France). Mean individual oyster flesh dry weight was

$1540.34 \pm 0.03 \mathrm{~g}$ and mean shell length was $61.7 \pm 1.9 \mathrm{~mm}($ mean \pm CI $5 \%, \mathrm{n}=60)$.

$155 \quad$ 2.1.2 Algal culture

156 Alexandrium minutum (strain AM89BM - isolated from the Bay of Morlaix, France, in 1989)

157 was grown in 10-liter batch culture using autoclaved seawater filtered through a 1- $\mu \mathrm{m}$ filter

158 and supplemented with L1 nutrient enrichment (Guillard and Hargraves, 1993). Cultures were

159 incubated at $16 \pm 1^{\circ} \mathrm{C}$ and $100 \mu \mathrm{mol}$ photon $\mathrm{m}^{-2} \mathrm{~s}^{-1}$, with a dark:light cycle of $12: 12 \mathrm{~h}$. A.

160 minutum was harvested after 12 days, still in exponential growth phase under our conditions.

161 At this stage, this strain produced $1.3 \pm 0.1$ pg saxitoxin equivalent (STX eq.) per cell

162 (measured by the method of Oshima, 1995).

163 Tisochrysis lutea (formerly Isochrysis sp., clone Tahitian) cultures were obtained from the

164 Argenton hatchery (Ifremer, France). Cultures were produced in 300-liter cylinders containing

1651 - $\mu \mathrm{m}$ filtered seawater enriched with Conway medium at $24 \pm 1^{\circ} \mathrm{C}$, air- $\mathrm{CO}_{2}$ (3\%) mix aerated,

166 and with continuous light. T. lutea was harvested in the exponential growth phase (4-5 days)

167 for the feeding experiments.

$168 \quad 2.2$ Experimental design of exposures

169 Short-term exposure period was chosen to enable comparison with previous experiments and

170 to mimic field event of harmful microalgal bloom (Haberkorn et al, 2010a and b). The applied

171 metals were $\mathrm{Cd}$ and $\mathrm{Cu}$ as they may have aggravating, synergistic effects. Concentrations

172 were chosen to be in the sublethal ranges (Auffret et al., 2002). Indeed, during present

173 experiment, no mortality was observed after four days of exposure.

174 To proceed, 240 oysters were placed randomly in twelve 15-liter tanks (20 oysters per tank).

175 Oysters were acclimated for 10 days with a continuous flow of $14 \mathrm{ml} \mathrm{min}^{-1}$ of seawater

176 (filtered through a $0.5-\mu \mathrm{m}$ filter) with $T$. lutea at $5.10^{5}$ cells $\mathrm{ml}^{-1}$ at $16 \pm 1^{\circ} \mathrm{C}$. After

177 acclimation, oysters were fed continuously for 4 days at $14 \mathrm{ml} \mathrm{min}^{-1}$ with $5.10^{5}$ cells $\mathrm{ml}^{-1}$ of $T$.

178 lutea (six control tanks) and with $5.10^{3}$ cells $\mathrm{ml}^{-1}$ of $A$. minutum (six A. minutum tanks). These 
179 two different cell densities were used to provide the same bio-volume of microalgae to oysters

180 as the cellular volume of $A$. minutum is about $100 x$ higher than that of T. lutea.

181 To half of the control and A. minutum tanks a mixture of $\mathrm{Cd}$ and $\mathrm{Cu}$ was also added. Separate

182 stock solutions of $\mathrm{Cd}$ and $\mathrm{Cu}$ were prepared in filtered sterile seawater (FSSW) at $250 \mathrm{mM}$

183 and $50 \mathrm{mM}$, respectively. A volume of 1,500, 750, 375 or $187.5 \mu \mathrm{l}$ of $\mathrm{Cd}$ and Cu stock

184 solutions was added at 0, 24, 48 and $72 \mathrm{~h}$ in each of the six tanks during 4 days (exposure).

185 Initial concentrations of $\mathrm{Cd}$ and $\mathrm{Cu}$ at T0 were $25 \mu \mathrm{M}\left(2.8 \mathrm{mg} \mathrm{l}^{-1}\right)$ and $5 \mu \mathrm{M}\left(0.317 \mathrm{mg} \mathrm{l}^{-1}\right)$

186 and contamination pressure was expected to be maintained constant for the 4 days of

187 experiment.

\section{$188 \quad 2.3$ Oyster sampling}

189 At the end of exposures (4 days), all oysters were sampled and processed as follows: from

190 each tank, pooled digestive glands from ten oysters were used to measure toxin accumulation,

191 Cd-Cu contents, neutral and polar lipid class composition, and amylase activity. Five oysters

192 were used for individual plasma and hemocyte variable measurements and condition index

193 assessments.

194 2.4 Digestive gland variables

195 Just after dissection, digestive glands were frozen immediately in liquid nitrogen, weighed,

196 pooled (1 pool of 10 digestive glands per tank), and stored at $-80^{\circ} \mathrm{C}$ until analysis. Later,

197 pools were ground with a Dangoumeau apparatus in liquid nitrogen and divided for four

198 different analyses (toxins, metals, lipids, amylase).

$199 \quad$ 2.4.1 Toxin content

200 One gram of ground digestive gland (DG) was extracted in $2 \mathrm{ml}$ of $0.1 \mathrm{~N} \mathrm{HCl}(2 \mathrm{v} / \mathrm{w})$ at $4^{\circ} \mathrm{C}$.

201 After centrifugation (3,000 × g, $\left.15 \mathrm{~min}, 4^{\circ} \mathrm{C}\right)$, the $\mathrm{pH}$ of each extract was adjusted below 3.0.

202 If above 3.0, $\mathrm{pH}$ was adjusted with $12 \mathrm{~N} \mathrm{HCl}$. After half-dilution, supernatants were ultra-

203 filtered (20 kDa, Sartorius Centrisart) and stored at $4^{\circ} \mathrm{C}$ until analysis. PSTs were analyzed by

204 ion-pairing, high-performance liquid chromatography (IPHPLC) according to the method of

205 Oshima (1995). The molar concentration ( $\mu \mathrm{mol} \mathrm{l}^{-1}$ ) was converted into $\mu \mathrm{g}$ STX eq. $100 \mathrm{~g}^{-1}$ of

206 digestive gland using the conversion factors of Oshima (1995). Results were expressed as

$207 \mu \mathrm{g}$ STX eq. $100 \mathrm{~g}^{-1}$ of digestive gland wet weight. 


\subsubsection{Analyses of cadmium and copper contents}

For measuring metal concentrations, aliquots of deep frozen, ground digestive glands were freeze-dried for 48 hours at $-55^{\circ} \mathrm{C}$ (CHRIST Alpha 1-2, Bioblock scientific). One-hundred mg of sample were dissolved in $2 \mathrm{ml}$ nitric acid (65\%, Suprapur, Merck). After dilution in $0.5 \mathrm{M}$ $\mathrm{NaCl}$ (SigmaUltra, Sigma), concentrations of copper and cadmium were assessed by stripping chronopotentiometric methods. These methods are detailed in Riso et al. (1997a and b) and were used previously for metal analysis in shellfish and fish tissues (Tanguy et al., 2003; Evrard et al., 2010).

\subsubsection{Lipid class contents}

Two-hundred and fifty mg of deep-frozen ground DG were extracted in $6 \mathrm{ml}$ of Folch solution (chloroform:methanol 2:1). Lipid classes were analyzed by high-performance, thinlayer chromatography (HPTLC) on HPTLC glass plates $(1,010 \mathrm{~mm})$ pre-coated with silica gel 60 from Merck (Darmstadt, Germany). A preliminary run was carried out to remove possible impurities using hexane:diethyl ether (1:1) prior to neutral lipid analysis and using methylacetate:iso-propanol:chloroform:methanol:KCl 0.25\% (10:10:10:4:3.6) prior to polar lipid analysis. Each plate was activated for $30 \mathrm{~min}$ at $110^{\circ} \mathrm{C}$. Lipid samples (4-6 $\left.\mu \mathrm{l}\right)$ were spotted on the plates by the CAMAG automatic sampler (CAMAG, Switzerland).

The neutral lipids were separated with a solvent system containing hexane:diethyl ether:acetic acid (20:5:0.5). The polar lipids were separated with a solvent system containing methylacetate:iso-propanol:chloroform:methanol: $\mathrm{KCl}$ 0.25\% (10:10:10:4:3.6).

Lipid classes appeared as black spots after dipping plates in a cupric-sulfate, phosphoric-acid solution and heating for $20 \mathrm{~min}$ at $160^{\circ} \mathrm{C}$ (charring). Seven neutral-lipid classes (free fatty acids, sterol esters, glycerid ethers, monoacylglycerol, diacylglycerol, triacylglycerol, sterols) and seven polar lipid classes (cardiolipin = bisphosphatidylglycerol, lysophosphatidylcholine, phosphatidylcholine, phosphatidylethanolamine, phosphatidylserine, phosphatidylinositol, ceramide aminoethylphosphonate) were identified based upon authentic standards (SigmaAldrich, France) and coloring techniques. The charred plates were read by scanning at 370 $\mathrm{nm}$, and black spots were quantified using Wincats software (CAMAG, Switzerland). Results were expressed as mg of each identified lipid class per g of digestive gland wet weight.

\subsubsection{Amylase activity}

Two hundred mg of deep frozen ground DG were homogenized in $1 \mathrm{ml}$ of distilled water. Two hundred $\mu \mathrm{l}$ of this solution were added to $10 \mu \mathrm{l}$ of a $0.5 \mathrm{M} \mathrm{CaCl}_{2}$ solution before 
analysis. Amylase activity was then assayed by determination of starch hydrolysis according to the iodine reaction (Samain et al., 1977) modified by Le Moine et al. (1997). One unit of alpha-amylase was defined as the amount of enzyme that degrades $1 \mathrm{mg} \cdot \mathrm{min}^{-1}$ starch at $45^{\circ} \mathrm{C}$. To assess specific activity of amylase, total proteins were determined using the BCA Protein Assay (Biorad). For protein extraction, $200 \mu \mathrm{l}$ of the above solution was added to $200 \mu \mathrm{l}$ of a $2 \mathrm{~N} \mathrm{NaOH}$ solution. Protein analysis was carried out on $10 \mu \mathrm{l}$ of 1/10 diluted samples according to the manufacturer's description. Briefly, $200 \mu \mathrm{l}$ of dye reagent was added to $10 \mu \mathrm{l}$ of sample and incubated at $37^{\circ} \mathrm{C}$ for 1 hour, and the absorbance was measured at $595 \mathrm{~nm}$. Sample ODs were compared to a standard curve of Bovine Serum Albumin (BSA), and results were expressed as mg protein. $\mathrm{ml}^{-1}$. Results were expressed as amylase specific activity (i.e. International Unit - IU - per mg of total protein).

\subsection{Hemolymph variables}

\subsubsection{Hemolymph sampling}

Hemolymph was withdrawn from individual oysters using a 1-ml plastic syringe fitted with a 25-gauge needle inserted through a notch made adjacent to the adductor muscle just prior to bleeding. All hemolymph samples were examined microscopically for contamination (e.g., gametes, tissue debris) and then stored in micro-tubes held on ice. As recommended by the flow cytometer (FCM) manufacturer, all samples were filtered through $80 \mu \mathrm{m}$ mesh prior to analysis to eliminate any large debris $(>80 \mu \mathrm{m})$ which could potentially clog the flow cytometer. Three hundred microliters ( 3 measures $\times 100 \mu$ l) of each hemolymph sample were used to measure hemocyte variables by flow cytometry.

The remaining hemolymph was separated into cellular (hemocytes) and supernatant (plasma) fractions by centrifugation $\left(800 \times \mathrm{g}, 5 \mathrm{~min}, 4^{\circ} \mathrm{C}\right)$ prior to freezing $\left(-20^{\circ} \mathrm{C}\right)$. These samples then were used to measure biochemical hemocyte and plasma variables (protein content and phenoloxydase activity).

Methods for measuring cellular (hemocyte) and humoral (plasma) variables are described hereafter.

\subsubsection{Measurements of hemocyte variables by flow cytometry}

Characterization of hemocyte sub-populations, number and functions, were performed using a FACScalibur (BD Biosciences, San Jose, CA, USA) flow cytometer (FCM) equipped with a $488 \mathrm{~nm}$ argon laser. Two kinds of hemocyte variables were evaluated by FCM: descriptive variables (hemocyte viability and total and hemocyte sub-population counts), and functional 
273 variables (phagocytosis and reactive oxygen species (ROS) production). Analyses were done

274 as described below.

275

276

2.5.2.1 Descriptive variables

277 Hemocyte viability, total and hemocyte sub-population counts were measured individually on

278 hemolymph samples (5 individuals per tank). An aliquot of $100 \mu \mathrm{l}$ of hemolymph was

279 transferred into a tube containing a mixture of Anti-Aggregant Solution for Hemocytes,

280 AASH (Auffret and Oubella, 1995) and filtered sterile seawater (FSSW), 200 and $100 \mu l$,

281 respectively. Hemocyte DNA was stained with two fluorescent DNA/RNA specific dyes,

282 SYBR Green I (Molecular probes, Eugene, Oregon, USA, 1/1,000 of the DMSO commercial

283 solution), and propidium iodide (PI, Sigma, St Quentin Fallavier, France, final concentration

284 of $10 \mu \mathrm{g} \mathrm{ml}^{-1}$ ) in the dark at $18^{\circ} \mathrm{C}$ for $120 \mathrm{~min}$ before flow cytometric analysis. PI permeates

285 only hemocytes that lose membrane integrity and are considered to be dead cells, whereas

286 SYBRGreen I permeates both dead and live cells. SYBR Green and PI fluorescence were

287 measured at 515-545 nm (green) and >670 nm (red) wavelengths, respectively, by flow

288 cytometry. Thus, by counting the cells stained by PI and cells stained by SYBR Green I, it

289 was possible to estimate the percentage of viable cells in each sample. All SYBR Green I-

290 stained cells were visualized on a Forward Scatter (FSC, size) and Side Scatter (SSC, cell

291 complexity) cytogram. Two main sub-populations were distinguished according to size and

292 cell complexity (granularity). Granulocytes are characterized by high FSC and high SSC,

293 while hyalinocytes by high FSC and low SSC. Total hemocyte, granulocyte and hyalinocyte

294 concentrations were estimated from the flow-rate measurement of the flow cytometer (Marie

295 et al., 1999) as all samples were run for 30 s. Results were expressed as number of cells per

296 milliliter of hemolymph.

297

$298 \quad$ 2.5.2.2 Functional variables

299 To measure phagocytosis rate, an aliquot of $100 \mu \mathrm{l}$ hemolymph, diluted with $100 \mu \mathrm{l}$ of FSSW, 300 was mixed with $30 \mu \mathrm{l}$ of Yellow-Green, 2.0- $\mu \mathrm{m}$ fluoresbrite microspheres, diluted to $2 \%$ in

301 FSSW (Polysciences, Eppelheim, Germany). After 120 min of incubation at $18^{\circ} \mathrm{C}$, hemocytes

302 were analyzed at $515-545 \mathrm{~nm}$ by flow cytometry to detect hemocytes containing fluorescent

303 beads. The phagocytosis rate was defined as the percentage of hemocytes that had engulfed

304 three or more beads (Delaporte et al., 2003).

305 Reactive oxygen species (ROS) production by hemocytes was measured using 2,7-

306 dichlorofluorescein diacetate, DCFH-DA (Lambert et al., 2003). A 100- $\mu$ l aliquot of 
307 hemolymph was diluted with $300 \mu \mathrm{l}$ of FSSW. Four $\mu \mathrm{l}$ of the DCFH-DA solution (final

308 concentration of $0.01 \mathrm{mM}$ ) was added to each tube maintained on ice. Tubes were then

309

310

311

312

313

314

315

316

317

318

319

320

321

322

323

324

325

326

327

328

329

330

331

332

333

334

335

336

337

338 incubated at $18^{\circ} \mathrm{C}$ for $120 \mathrm{~min}$. After the incubation period, DCF fluorescence, quantitatively related to the ROS production of hemocytes, was measured at $515-545 \mathrm{~nm}$ by flow cytometry. Results were expressed as the geometric mean fluorescence (in arbitrary units, AU) detected in each hemocyte sub-population.

\subsubsection{Hemocyte and plasma phenoloxidase activities}

Plasma samples were thawed on ice, and $100 \mu \mathrm{l}$ of each was transferred to a well in a 96-well plate. For hemocytes, cells were suspended in $100 \mu \mathrm{l}$ of FSSW and frozen and thawed on ice three times successively. Phenoloxidase activity was measured as described by Reid et al. (2003). Briefly, $50 \mu \mathrm{l}$ of Tris-HCl buffer $(0.2 \mathrm{M}, \mathrm{pH}=8)$ and $100 \mu \mathrm{l}$ of l-DOPA (20 mM, l3,4-dihydrophenyl-alanine, Sigma D9628) were added to each well. The microplate was mixed rapidly for $10 \mathrm{~s}$. The reaction then was measured at ambient temperature, with color change recorded every $5 \mathrm{~min}$, at $492 \mathrm{~nm}$, over a period of $1 \mathrm{~h}$. The microplate was mixed prior to each measurement. Two controls, without sample but containing l-DOPA and TrisSDS buffer, were measured in parallel, and these values were subtracted from test values to correct for possible auto-oxidation of the l-DOPA and buffer absorbance. To assess specific activity of phenoloxidase, total proteins in hemocyte suspension and plasma were determined using the BCA Protein Assay (Biorad). Protein analysis was carried out on $10 \mu \mathrm{l}$ samples according to the manufacturer's description. Briefly, $200 \mu \mathrm{l}$ of dye reagent was added to $10 \mu \mathrm{l}$ of sample and incubated at $37^{\circ} \mathrm{C}$ for 1 hour, and the absorbance was measured at $595 \mathrm{~nm}$. Sample ODs were compared to a standard curve of Bovine Serum Albumin (BSA), and results were expressed as mg protein. $\mathrm{ml}^{-1}$. Results were expressed as specific activity of phenoloxidase (i.e. International Unit - IU - per mg of total protein).

\subsection{Statistical analysis}

Results of toxin and metal contents were analyzed statistically using one-way ANOVA. Results of each experiment were analyzed statistically using two-way ANOVA for each physiological variable and hemocyte variable as the dependent variable, and exposure conditions as independent variables.

In conjunction with two-way ANOVA, Tukey's HSD test were performed to find means that are significantly different from each other. 
339 Variables expressed as percentages were transformed as arcsin(squareroot) before statistical 340 analysis, but presented as non transformed data in figures.

341 Statistical analyses were performed using Statgraphics Plus statistical software (Manugistics, 342 Inc, Rockville, MD, USA). Differences were considered significant when p-value was $<0.05$. 343 
343

344

345

346

347

348

349

350

351

352

353

354

355

356

357

358

359

360

361

362

363

364

365

366

367

368

369

370

371

372 375

376

373 There was no significant difference in free fatty acid, triacylglycerol and sterol ester contents 374 between treatments (Table 1).

\section{Results}

\subsection{Digestive gland variables}

\subsubsection{Toxin content}

PST content in the digestive gland was significantly higher $(\mathrm{p}=0.0001$, ANOVA $)$ in oysters exposed to A. minutum alone than in oysters exposed to both A. minutum and cadmiumcopper (Fig. 1). No PSTs were detected in oysters exposed to T. lutea with and without Cd$\mathrm{Cu}$.

\subsubsection{Cadmium and copper contents}

There were no significant differences in cadmium and copper contents in digestive gland of exposed oysters regardless of dietary condition (Fig. 2). Cd and Cu were not detected in oysters exposed to microalgae alone.

\subsubsection{Neutral lipid contents}

There was no significant difference in total neutral lipid contents between treatments (Table 1).

Monoacylglycerol (MAG) content was significantly lower in oyster fed A. minutum than in those fed $T$. lutea. In metal-exposed oyster, whatever the diet, the content was significantly lower than in T. lutea control and higher than in A. minutum control. MAG were significantly affected by the interaction between $\mathrm{Cd}-\mathrm{Cu}$ and diet.

Diacylglycerol (DAG) content was significantly lower in oysters exposed to A. minutum as compared to those exposed to $T$. lutea and was significantly higher in oysters exposed to $\mathrm{Cd}$ $\mathrm{Cu}$ as compared to non-exposed oysters (Table 1).

Content of sterols was significantly lower in oysters exposed to $\mathrm{Cd}-\mathrm{Cu}$ (Table 1).

In control condition, ether glyceride content was significantly higher in oysters fed $T$. lutea than in those exposed to A. minutum. Interaction between diet and $\mathrm{Cd}-\mathrm{Cu}$ exposure significantly affected ether glycerides with non exposed oysters fed $T$. lutea having the highest level (Table 1). 
377 Total phospholipid content (Table 2) was significantly lower in digestive glands of oysters

378 exposed to $\mathrm{Cd}-\mathrm{Cu}$ and fed $A$. minutum as compared to non-exposed oysters.

379 Phosphatidylcholine (PC) and cardiolipin (CL) were significantly lower in oysters exposed to

380 Cd-Cu and fed A. minutum than in non-exposed oysters (Table 2). Phosphatidylethanolamine

381 (PE) and ceramide aminoethylphosphonate (CAEP) were significantly lower in oysters

382 exposed to $\mathrm{Cd}-\mathrm{Cu}$ as compared to non-exposed oysters (Table 2).

383 There was no significant difference in lysophosphatidylcholine (LPC), phosphatidylionsitol

384 (PI) and phosphatidylserine (PS) contents between treatments (Table 2).

385

386

3.1.5 Amylase specific activity

387

There was no significant variation of the amylase specific activity in digestive gland between

388 different exposure conditions.

389

390

3.2 Hemolymph variables

391

392

\subsubsection{Hemocyte variables}

393 Overall, Cd-Cu exposure had more significant effects upon hemocyte and plasma variables

394 than A. minutum exposure (Table 3).

395 Total hemocyte counts (THC) were significantly higher in oysters exposed to Cd-Cu and fed

396 T. lutea and also were affected by the interaction between $\mathrm{Cd}-\mathrm{Cu}$ exposure and dietary

397 treatment (Fig. 3A, Table 3).

398 Percentage of dead hemocytes was significantly higher in oysters exposed to $\mathrm{Cd}-\mathrm{Cu}$, 399 especially in those fed T. lutea (Fig. 3B, Table 3).

400 Percentage of phagocytic hemocytes was significantly lower in oysters exposed to $\mathrm{Cd}-\mathrm{Cu}$

401 (Fig. 3C, Table 3). Phagocytosis was also significantly higher in oysters fed A. minutum in

402 relation to those fed T. lutea.

403 ROS production by granulocytes was significantly lower in oysters exposed to $\mathrm{Cd}-\mathrm{Cu}$ as

404 compared to non-exposed oysters fed A. minutum (Fig. 3D, Table 3). Similarly, ROS

405 production of hyalinocytes was greatly reduced upon exposure to $\mathrm{Cd}-\mathrm{Cu}$ (Table 3).

406

407

3.2.2 Hemocyte and plasma phenoloxidase (PO) specific activities

408 PO specific activity in hemocytes was higher in oysters exposed to $\mathrm{Cd}-\mathrm{Cu}$ as compared to

409 non-exposed oysters (Fig. 3E, Table 3). PO specific activity in plasma was higher in oysters

410 exposed to A. minutum than in oysters fed T. lutea (Fig. 3F, Table 3). In plasma, this activity 
411 was higher in oysters exposed to $\mathrm{Cd}-\mathrm{Cu}$ and $\mathrm{A}$. minutum as compared to non-exposed oysters 412 fed T. lutea (Fig. 3F).

413 


\section{Discussion}

414

415 Effects of combined exposure to $\mathrm{Cd}-\mathrm{Cu}$ and $\underline{\mathrm{A} \text {. minutum }}$ on phycotoxin and metal 416 accumulations.

417 One of the most striking results of this experiment was the difference in PST accumulation in 418 digestive glands of $\mathrm{Cd}-\mathrm{Cu}$ exposed and non-exposed oysters. Oysters exposed to $\mathrm{Cd}-\mathrm{Cu}$ 419 accumulated about thirty-six times less PSTs as compared to oysters exposed to A. minutum 420 only. Such lower toxin accumulation could be explained by a decrease in feeding activity ( $A$. 421 minutum cell ingestion) and/or by alteration of digestive processes. In Corbicula fluminea, 422 Tran et al. (2003a and b) observed a prolonged closure of valves in reaction to dissolved 423 copper or cadmium, suggesting a decrease in feeding activity. Similarly, decreased filtration 424 rate has been observed in C. gigas exposed to copper or cadmium (Lin et al., 1992; Lin et al., 425 1993). Modification of lipid composition of the digestive gland, described hereafter, may also 426 reflect some alterations of digestive processes resulting in lower toxin accumulation by $\mathrm{Cd}-\mathrm{Cu}$ 427 exposed oysters as a lower digestive efficiency may lead to a lower toxin uptake. Another 428 hypothesis is that alteration of phytoplanktonic cells may result in decreased ingestion by 429 oysters. Cyst formation by A. minutum, however, was observed only when A. minutum cells 430 were exposed to $\mathrm{Cd}-\mathrm{Cu}$ at higher concentrations than those applied in this experiment (data 431 not shown). Even though some physiological changes may have occurred in microalgae upon exposure to $\mathrm{Cd}-\mathrm{Cu}$ in the oyster tank, they are unlikely to explain observed differences in toxin accumulation by oysters.

434

435 On the other hand, harmful organisms such as pathogens and toxic phytoplankton are 436 expected to modify chemical contaminant accumulation by interfering with nutritional 437 processes and reducing general oyster fitness. In Cerastoderma edule, Paul-Pont et al. (2010) 438 observed that the presence of pathogens decreased cadmium bioaccumulation both in gills and 439 visceral mass when cockles were concomitantly exposed to pathogens. Decrease in pollutant 440 accumulation in parasitized individuals has been demonstrated in several host-parasite models 441 (Evans et al., 2001; Sures, 2008). In the present study, however, exposure to a toxic

442 dinoflagellate did not modulate accumulation of $\mathrm{Cd}-\mathrm{Cu}$.

444 Levels of accumulated metals in digestive glands of oysters (from 335.1 to $392.8 \mu \mathrm{g} \mathrm{g}^{-1}$ dry 445 weight for $\mathrm{Cd}$ and 115.8 to $145.4 \mu \mathrm{g} \mathrm{g}^{-1} \mathrm{DW}$ for $\mathrm{Cu}$ ) measured in the present study were 446 comparable to oysters reared in contaminated areas. Body burden of cadmium in field oyster 
447 populations (Crassostrea virginica) ranged from 300 to $400 \mu \mathrm{g} \mathrm{g}^{-1} \mathrm{DW}$ (Roesijadi, 1996).

448 Abbe et al. (2000) observed that field Cu contamination in C. virginica reached $310 \mu \mathrm{g} \mathrm{g}^{-1}$

449 DW. Concentration of $850 \mu \mathrm{g} \mathrm{g}^{-1} \mathrm{DW}$ for the same species was also observed by O-Connor

450 and Lauenstein (2005). Concentration of cadmium reached $5 \mu \mathrm{g} \mathrm{g}^{-1}$ wet weight and

451 concentration of copper reach at $300 \mathrm{\mu g} \mathrm{g}^{-1}$ digestive gland WW in C. gigas from a polluted

452 estuary (Mouneyrac et al., 1998).

453

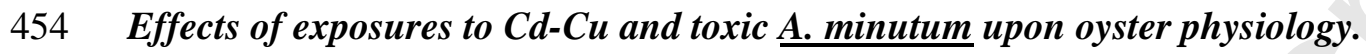

455 The present results demonstrated major effects of $\mathrm{Cd}-\mathrm{Cu}$ upon lipid composition of the oyster

456 digestive gland. Exposure to Cd-Cu induced decreases in sterols, PC, PE, CAEP and CL.

457 Variations in lipid contents were probably not linked to lipid hydrolysis because no increase

458 in FFA was observed (Chu et al., 2003). Changes in PL composition may reflect some

459 changes in cell types or in organelles as changes in cell type composition is a general

460 phenomenon that can take place in the digestive gland epithelia of mollusks stressed by

461 chemical contamination, as underscored by Zaldibar et al. (2008). A recent study (Zaldibar et

462 al., 2007) demonstrated that exposure of winkles (Littorina littorea) to Cd resulted in changes

463 in the epithelia of the digestive gland (digestive ducts and tubules). These changes were

464 characterized by a loss of digestive cells (minus 13.2\%) and volume increases in both

465 digestive and basophilic cells (plus 13.5\% and 200\%, respectively). Variations in PL

466 composition could also be linked to perturbations of lipid metabolism and/or to lipid

467 peroxidation. Ringwood et al. (1998) observed significant increase in lipid peroxidation in

468 oysters, C. virginica, exposed to copper. Similarly, Géret et al. (2002) observed that exposure

469 of Mytilus edulis to cadmium stimulated lipid peroxidation processes through oxidation of

470 polyunsaturated fatty acids. Also, exposure of Ruditapes decussatus to cadmium led to

471 changes in protein-expression profiles, including cell maintenance (Rab GDP dissociation

472 inhibitor $\alpha$-mediators of vesicle formation, trafficking, and fusion) and metabolism (MCAD

473 - medium chain-CoA dehydrogenase, enzyme responsible for the metabolism of medium

474 chain fatty acids - and ALDH - aldehyde dehydrogenase, mitochondrial precursor)

475 suggesting potential alteration in energetic processes (Chora et al., 2009).

476 Effects of A. minutum exposure upon lipid composition of the digestive gland were mainly

477 characterized by decreases in MAG, DAG and ether glycerides. Such effects of $A$. minutum

478 upon oysters were reported previously by Haberkorn et al. (2010b).

479 
Effects of $\mathrm{Cd}-\mathrm{Cu}$ exposure were observed in most of the measured hemocyte variables:

481

482

483

484

485

486

487

488

489

490

491

492

493

494

495

496

497

498

499

500

501

502

503

504

505

506

507

508

509

510

511

512

513

increases in total hemocyte count, percentage of dead hemocyte and phenoloxidase activity, as well as decreases in phagocytosis and ROS production. Oysters may possibly increase circulating hemocytes to compensate for increase in mortality. Other studies previously reported that increases in circulating hemocytes in C. virginica exposed to cadmium were associated with increased percentage of dead hemocytes (Cheng, 1988; Cheng, 1990). Similarly, Auffret et al. (2002) observed increases in THC in oysters, Ostrea edulis, exposed to $\mathrm{Cd}-\mathrm{Cu}$.

Decreased hemocyte phagocytosis upon $\mathrm{Cd}-\mathrm{Cu}$ exposure also has been observed in O. edulis (Auffret et al., 2002). Auffret et al. (2002) similarly observed a decrease in ROS production in hemocytes in oysters, O. edulis, exposed in vivo to a high concentration of cadmium (50 $\mu \mathrm{M})$. The present results clearly suggest an alteration of some hemocyte-based defense mechanisms by $\mathrm{Cd}-\mathrm{Cu}$ exposure.

Feeding oysters on A. minutum resulted in less intense immunomodulation than $\mathrm{Cd}-\mathrm{Cu}$ exposure. Hemocyte phagocytosis increased upon A. minutum exposure. Such stimulation of phagocytosis has been observed previously in hemocytes of the blue mussel, Mytilus edulis, exposed to Karlodinium veneficum (Galimany et al., 2008c). Observations suggest a stimulation of this cellular-based immune function when bivalves feed on harmful microalgae.

\section{Combined effects and interactions of exposures to $\mathrm{Cd}-\mathrm{Cu}$ and toxic $\underline{\mathrm{A} \text {. minutum upon }}$} oyster physiology.

Oysters exposed to both metals and harmful algae accumulated large amounts of Cd-Cu but only a small quantities of PST, suggesting that effects in these exposures may be primarily from metals. Nevertheless, results of co-exposure were different than those of single “contaminant” exposure.

Effects of Cd-Cu exposure on lipids were opposite to those caused by A. minutum feeding: Cd-Cu exposure counteracted the decreasing effect of A. minutum on MAG, DAG and ether glycerides. Such interactive effects of $\mathrm{Cd}-\mathrm{Cu}$ and $\mathrm{A}$. minutum exposures on lipid metabolism within the digestive gland need further investigation.

Total hemoctye counts (THC) and percentages of dead hemocytes increased dramatically in oysters fed T. lutea and exposed to Cd-Cu. But when oysters were fed A. minutum, this effect 
514 was subdued, revealing that oysters exposure to A. minutum interacts antagonistically with

515 Cd-Cu exposure. Similarly, Cd-Cu exposure resulted in a large decrease in hemocyte

516 phagocytosis which indeed counteracted the stimulating effect of A. minutum on

517 phagocytosis, revealing opposite effects.

518 The highest values of PO in plasma were found in oysters fed $A$. minutum and exposed to $\mathrm{Cu}-$

519 Cd. This increase was mostly attributable to $\mathrm{Cu}-\mathrm{Cd}$ exposure. This is in agreement with the

520 study of Bouilly et al. (2006) who observed an increase in PO activity in C. gigas exposed to

521 cadmium. Our results suggest synergistic effects of $A$. minutum and Cd-Cu upon PO activity.

522

523 As some effects upon oysters were apparently not linked to PST accumulation in Cd-Cu

524 exposed oysters (i.e. oysters exposed to both $A$. minutum and $\mathrm{Cd}-\mathrm{Cu}$ accumulate a few PST),

525 these results suggested that responses of oysters to A. minutum was not only because of PST

526 but also caused by other compounds released by the microalgae or membrane bound (Arzul et

527 al., 1999; Emura et al., 2004; Ford et al., 2008;Tillmann et al., 2008; Lelong et al., 2011).

528

529 This preliminary study underscores the complexity of multiple stress interactions. Although

530 these two stressors have concentration-dependent effects (Auffret et al., 2002; Bouilly et al.,

531 2006, Hégaret et al., 2007a; Haberkorn et al., 2011), it appeared that Alexandrium species

532 exposures have less severe effects upon oyster physiology than $\mathrm{Cd}$ and $\mathrm{Cu}$. This may simply

533 reflect the fact that tested concentrations of metals were quite high. Nevertheless, the present

534 results also suggest that simultaneous exposure to metal (Cd-Cu) and harmful microalgae (A.

535 minutum) can have antagonistic (for example in hemocyte phagocytosis) or synergistic (for

536 example in PO activity) effects on oysters. This is in agreement with observations previously

537 reported in multiple stressors exposure in bivalves (Hégaret et al., 2007b; Da Silva et al.,

538 2008; Paul-Pont et al., 2010). It remains to be elucidated when toxic metals and HAB are

539 interacting through oyster nutritional processes and what are the biochemical and cellular

540 involved mechanisms in these interactions.

541

542 Acknowledgment

543 The authors are grateful to Gary H. Wikfors for English corrections, as well as to anonymous

544 reviewers for their helpful comments and suggestions. This study was carried out with the

545 financial support of the National Research Agency (ANR) “'MODECOPHY” project

546 06SEST23 (2006-2009) and of the Brittany Region, “EPHYTOX” project. 


\section{References}

548 Abbe, G.R., Riedel, G.F., Sanders, J.G., 2000. Factors that influence the accumulation of

549

550

551

552

553

554

555

556

557

558

559

560

561

562

563

564

565

566

567

568

569

570

571

572

573

574

575

576

577

578 copper and cadmium by transplanted eastern oysters (Crassostrea virginica) in the Patuxent River, Maryland. Mar. Environ. Res. 49, 377-396.

Arzul, G., Seguel, M., Guzman, L., Erard-Le Denn, E., 1999. Comparison of allelopathic properties in three toxic Alexandrium species. J. Exp. Mar. Biol. Ecol. 232, 285-295.

Auffret, M., Oubella, R., 1995. Cytological and cytometric analysis of bivalve mollusc hemocytes. Techniques in Fish Immunology. 4, 55-63.

Auffret, M., Mujdzic, N., Corporeau, C., Moraga, D., 2002. Xenobiotic-induced immunomodulation in the European flat oyster, Ostrea edulis. Mar. Environ. Res. 54, 585-589.

Baars A.J., Theelen R.M.C., Janssen P.J.C.M., Hesse J.M., van Apeldoorn M.E., Meijerink M.C.M., Verdam L., Zeilmaker M.J., 2001 - Re-evaluation of human-toxicological maximum permissible risk levels RIVM, Rijsinstituut voor volksgezondheid en milieu. Report 711701025.

Baudrimont, M., de Montaudouin, X., 2007. Evidence of altered protective effect of metallothioneins after cadmium exposure in the digenean parasite-infected cockle (Cerastoderma edule). Parasitology. 134, 237-245.

Bouilly, K., Gagnaire, B., Bonnard, M., Thomas-Guyon, H., Renault, T., Miramand, P., Lapègue, S., 2006. Effects of cadmium on aneuploidy and hemocyte parameters in the Pacific oyster, Crassostrea gigas. Aquat. Toxicol. 78, 149-156.

Bricelj, V.M., Shumway, S.E., 1998. Paralytic Shellfish Toxins in bivalve molluscs: occurrence, transfer kinetics, and biotransformation. Res. Fish. Sci. 6, 315-383.

Cheng, T.C., 1988. In vivo effects of heavy metals on cellular defense mechanisms of Crassostrea virginica: total and differential cell counts. J. Invertebr. Pathol. 51, 207214.

Cheng, T.C., 1990. Effects of In Vivo Exposure of Crassostrea virginica to Heavy Metals on Hemocyte Viability and Activity Levels of Lysosomal Enzymes. Academic Press, San Diego, CA, USA.

Cherkasov, A.S., Grewal, S., Sokolova, I.M., 2007. Combined effects of temperature and cadmium exposure on haemocyte apoptosis and cadmium accumulation in the eastern oyster Crassostrea virginica (Gmelin). J. Therm. Biol. 32, 162-170. 
581

582

583

584

585

586

587

588

589

590

591

592

593

594

595

596

597

598

599

600

601

602

603

604

605

606

607

608

609

610

611

612

Chora, S., Starita-Geribaldi, M., Guigonis, J.M.., Samson, M., Roméo, M., Bebianno, M.J., 2009. Effect of cadmium in the clam Ruditapes decussatus assessed by proteomic analysis. Aquat. Toxicol. 94, 300-308.

Chu, F.L.E., Soudant, P., Hale, R.C., 2003. Relationship between PCB accumulation and reproductive output in conditioned oysters Crassostrea virginica fed a contaminated algal diet. Aquat. Toxicol. 65, 293-307.

Da Silva, P.M., Hégaret, H., Lambert, C., Wikfors, G.H., Le Goïc, N., Shumway, S.E., Soudant, P., 2008. Immunological responses of the Manila clam (Ruditapes philippinarum) with varying parasite (Perkinsus olseni) burden, during a long-term exposure to the harmful alga, Karenia selliformis, and possible interactions. Mar. Pollut. Bull. 50, 733-739.

Dailianis, S., 2009. Production of superoxides and nitric oxide generation in haemocytes of mussel Mytilus galloprovincialis (Lmk.) after exposure to cadmium: A possible involvement of $\mathrm{Na}^{+} / \mathrm{H}^{+}$exchanger in the induction of cadmium toxic effects. Fish Shellfish Immunol. 27, 446-453.

Delaporte, M., Soudant, P., Moal, J., Lambert, C., Quéré, C., Miner, P., Choquet, G., Paillard, C., Samain, J.F., 2003. Effect of a mono-specific algal diet on immune functions in two bivalve species_-Crassostrea gigas and Ruditapes philippinarum. J. Exp. Biol. 206, 3053-3064.

Donaghy, L., Lambert, C., Choi, K-S, Soudant, P., 2009. Hemocytes of the carpet shell clam (Ruditapes decussatus) and the Manila clam (Ruditapes philippinarum): Current knowledge and future prospects. Aquaculture. 297, 10-24.

Dorsey, A., Ingerman, L., Swarts, S., 2004. Toxicological profile for copper. Agency for Toxic Substances and Disease Registry. United States. 314 p.

Emura, A., Matsuyama, Y., Oda, T., 2004. Evidence for the production of a novel proteinaceous hemolytic exotoxin by dinoflagellate Alexandrium taylori. Harmful Algae. 3, 29-37.

Evans, D.W., Irwin, S.W.B., Fitzpatrick, S., 2001. The effect of digenean (Platyhelminthes) infections on heavy metal concentrations in Littorina littorea. J. Mar. Biol. Ass. U.K. 81, 349-350.

Evrard, E., Devaux, A., Bony, S., Burgeot,T., Riso R., Budzinski, H., Le Du, M., Quiniou, L., Laroche, J., 2010. Responses of the European flounder Platichthys flesus to the chemical stress in estuaries: load of contaminants, gene expression, cellular impact and growth rate. Biomarkers. 15(2) 111 - 127. 
613 Faroon, O., Ashizawa, A., Wright, S., Tucker, P., Jenkins, K., Ingerman, L., Rudisill, C.,

614

615

616

617

618

619

620

621

622

623

624

625

626

627

628

629

630

631

632

633

634

635

636

637

638

639

640

641

642

643

644

645

646 2012. Agency for Toxic Substances and Disease Registry. United States. 487 p.

Ford, S.E., Bricelj, V.M., Lambert, C., Paillard, C., 2008. Deleterious effects of a nonPST bioactive compound(s) from Alexandrium tamarense on bivalve hemocytes. Mar. Biol. 154, 241-253.

Gagné, F., Auclair, J., Turcotte, P., Fournier, M., Gagnon, C., Sauvé, S., Blaise, C., 2008. Ecotoxicity of CdTe quantum dots to freshwater mussels: Impacts on immune system, oxidative stress and genotoxicity. Aquat. Toxicol. 86, 333-340.

Galimany, E., Sunila, I., Hégaret, H., Ramón, M., Wikfors, G.H., 2008a. Experimental exposure of the blue mussel (Mytilus edulis, L.) to the toxic dinoflagellate Alexandrium fundyense: histopathology, immune responses, and recovery. Harmful Algae. 7, 702-711.

Galimany, E., Sunila, I., Hégaret, H., Ramón, M.,Wikfors, G.H., 2008b. Pathology and immune response of the blue mussel (Mytilus edulis L.) after an exposure to the harmful dinoflagellate Prorocentrum minimum. Harmful Algae. 7, 630-638.

Galimany, E., Place, A.R., Ramón, M., Jutson, M., Pipe, R.K., 2008c. The effects of feeding Karlodinium veneficum (PLY \# 103; Gymnodinium veneficum Ballantine) to the blue mussel Mytilus edulis. Harmful Algae. 7, 91-98.

Géret, F., Jouan, A., Turpin, V., Bebianno, M.J., Cosson, R.P., 2002. Influence of metal exposure on metallothionein synthesis and lipid peroxidation in two bivalve mollusks: the oyster (Crassostrea gigas) and the mussel (Mytilus edulis). Aquat. Living Resour. 15, 61-66.

Guillard, R.R.L., Hargraves, P.E., 1993. Stichochrysis immobilis is a diatom, not a chrysophyte. Phycologia. 32, 234-236.

Haberkorn, H., 2009. Impact du dinoflagellé toxique, Alexandrium minutum, sur l’huître creuse, Crassostrea gigas : approche intégrative. Thesis. Université de Bretagne Occidentale. $174 \mathrm{p}$.

Haberkorn, H., Lambert, C., Le Goïc, N., Guéguen, M., Moal, J., Palacios, E., Lassus, P., Soudant, P., 2010a. Effects of Alexandrium minutum exposure on physiological and hematological variables of diploid and triploid oysters, Crassostrea gigas. Aquat. Toxicol. 97, 96-108.

Haberkorn, H., Lambert, C., Le Goïc, N., Moal, J., Suquet, M., Guéguen, M., Sunila, I., Soudant, P., 2010b. Effects of Alexandrium minutum exposure on nutrition-related processes and reproductive output in oysters Crassostrea gigas. Harmful Algae. 9, 
647

648

649

650

651

652

653

654

655

656

657

658

659

660

661

662

663

664

665

666

667

668

669

670

671

672

673

674

675

676

677

678

679

427-439.

Haberkorn, H., Tran, D., Massabuau, J-C., Ciret, V., Savar, P. \& Soudant, P., 2011.

Relationship between valve activity, microalgae concentration in the water and toxin accumulation in the digestive gland of the Pacific oyster, Crassostrea gigas, exposed to Alexandrium minutum. Mar. Pollut. Bull. 62, 1191-1197.

Hégaret, H., Wikfors, G., Soudant, P., Lambert, C., Shumway, S., Bérard, J., Lassus, P., 2007a. Toxic dinoflagellates (Alexandrium fundyense and A. catenella) have minimal apparent effects on oyster hemocytes. Mar. Biol. 152, 441-447.

Hégaret, H., da Silva, P.M., Wikfors, G.H., Lambert, C., De Bettignies, T., Shumway, S.E., Soudant, P., 2007b. Hemocyte responses of Manila clams, Ruditapes philippinarum, with varying parasite, Perkinsus olseni, severity to toxic-algal exposures. Aquat. Toxicol. 84, 469-479.

Huss, H.H., 2003. Aquatic biotoxins. Chapter 5.1.5. In: Huss, H.H., Ababouch, L., Gram, L. (Eds.), Assessment and Management of Seafood Safety and Quality. FAO Fisheries Technical Paper, p. 239.

International Agency for Research on Cancer (IARC). CADMIUM AND CADMIUM COMPOUNDS VOL.: 58 (1993) (p. 119)

Lambert, C., Soudant, P., Choquet, G., Paillard, C., 2003. Measurement of Crassostrea gigas hemocyte oxidative metabolism by flow cytometry and the inhibiting capacity of pathogenic vibrios. Fish Shellfish Immunol. 15, 225-240.

Landsberg, J.H., 2002. The effects of harmful algal blooms on aquatic organisms. Fish. Sci. 10, 113-390.

Lassus, P., Bardouil, M., Ledoux, M., Murail, I., Bohec, M., Truquet, P., Frémy, J.-M., Rohmer, V., 1992. Paralytic phycotoxin uptake by scallops (Pecten maximus). Aquat. Living Resour. 5, 319-324.

Lelong, A., Haberkorn, H., Le Goïc, N., Hégaret, H., \& Soudant, P., 2011. A New Insight into Allelopathic Effects of Alexandrium minutum on Photosynthesis and Respiration of the Diatom Chaetoceros neogracile Revealed by Photosynthetic-performance Analysis and Flow Cytometry. Microb. Ecol. 62(4), 919-930.

Le Moine, S., Sellos, D., Moal, J., Daniel, J.Y., San Juan, S.F., Samain, J.F., Van Wormhoudt, A., 1997. Amylase on Pecten maximus (mollusca, bivalves): protein and cdna characterization; quantification of the expression in the digestive gland. Mol. Mar. Biol. Biotechnol. 6, 228-237. 
680

681

682

683

684

685

686

687

688

689

690

691

692

693

694

695

696

697

698

699

700

701

702

703

704

705

706

707

708

709

710

711

712

713

Lekhi, P., Cassis, D., Pearce, C.M., Ebell, N., Maldonado, M.T., Orians, K.J., 2008. Role of dissolved and particulate cadmium in the accumulation of cadmium in cultured oysters (Crassostrea gigas). Sci. Total Environ. 393, 309-325.

Lin, W., Rice, M.A., Chien, P.K., 1992. The effects of copper, cadmium and zinc on particle filtration and uptake of glycine in the pacific oyster Crassostrea gigas. Comp. Biochem. Physiol. C Comp. Pharmacol. 103, 181-187.

Lin, W., Rice, M.A., Chien, P.K., 1993. The differential effects of three heavy metals on particle filtration and amino acid uptake by the Pacific oyster, Crassostrea gigas. J. Shellfish Res. 12, 111 p.

Marie, D., Partensky, F., Vaulot, D., Brussaard, C., 1999. Enumeration of phytoplankton, bacteria, and viruses in marine samples. In: Curr. Protoc. Cytom. John Wiley \& Sons Inc., New York, pp. 11.11.11-11.11.15.

Morley, N.J., 2010. Interactive effects of infectious diseases and pollution in aquatic mollusks. Aquat. Toxicol. 96, 27-36.

Mouneyrac, C., Amiard, J.C., Amiard-Triquet, C., 1998. Effects of natural factors (salinity and body weight) on cadmium, copper, zinc and metallothionein-like protein levels in resident populations of oysters Crassostrea gigas from a polluted estuary. Mar. Ecol. Prog. Ser. 162, 125-135.

Narahashi, T., 1988. Mechanism of tetrodotoxin and saxitoxin action. In: Tiu, A.T. (Ed.), Handbook of Natural Toxins. Marine Toxins and Venoms, vol. 3. Marcel Dekker Inc., New York, pp. 185-210.

O’Connor, T.P., Lauenstein, G.G., 2005. Status and trends of copper concentrations in mussels and oysters in the USA. Mar. Chem. 97, 49-59.

Oshima, Y., 1995. Postcolumn derivatization liquid chromatographic method for paralytic shellfish toxins. J AOAC Int. 78, 528-532.

Parry, H.E., Pipe, R.K., 2004. Interactive effects of temperature and copper on immunocompetence and disease susceptibility in mussels (Mytilus edulis). Aquat. Toxicol. 69, 311-325.

Paul-Pont, I., Gonzalez, P., Baudrimont, M., Jude, F., Raymond, N., Bourrasseau, L., Le Goïc, N., Haynes, F., Legeay, A., Paillard, C., de Montaudouin, X., 2010. Interactive effects of metal contamination and pathogenic organisms on the marine bivalve Cerastoderma edule. Mar. Pollut. Bull. 60, 515-525.

Pipe, R.K. and Coles, J.A., 1995. Environmental contaminants influencing immune function in marine bivalve molluscs. Fish Shellfish Immunol. 5, 581-595. 
714

715

716

717

718

719

720

721

722

723

724

725

726

727

728

729

730

731

732

733

734

735

736

737

738

739

740

741

742

743

744

745

Pipe, R.K., Coles, J.A., Carissan, F.M.M., Ramanathan, K., 1999. Copper induced immunomodulation in the marine mussel, Mytilus edulis. Aquat. Toxicol. 46, 43-54.

Reid, H.I., Soudant, P., Lambert, C., Paillard, C., Birkbeck, T.H., 2003. Salinity effects on immune parameters of Ruditapes philippinarum challenged with Vibrio tapetis. Dis. Aquat. Org. 56, 249-258.

Réseau d'Observation de la Contamination Chimique du milieu marin (ROCCH/RNO). Institut français de recherche pour l'exploitation de la mer (IFREMER). http://wwz.ifremer.fr/envlit/surveillance/contaminants chimiques

Ringwood, A.H., Conners, D.E., DiNovo, A., 1998. The effects of copper exposures on cellular responses in oysters. Mar Environ Res. 46, 591-595.

Riso, R.D., Monbet, P., Corre, P.L., 1997a. Measurement of Copper in Sea-water by Constant Current Stripping Analysis (CCSA) With a Rotating Gold Disk Electrode. The Analyst, 122(12), 1593-1596.

Riso, R.D., Le Corre, P., Chaumery, C.J., 1997b. Rapid and simultaneous analysis of trace metals $(\mathrm{Cu}, \mathrm{Pb}$ and $\mathrm{Cd})$ in seawater by potentiometric stripping analysis. Anal. Chim. Acta. 351(1-3), 83-89.

Roesijadi, G., 1996. Environmental factors: Response to metals. In: Kennedy,V.S., Newell, R.I.E., Eble A.F. (Eds.), The Eastern Oyster Crassostrea virginica. A Maryland Sea Grant Book. College Park Maryland, pp. 515-537.

Samain, J.F., Daniel, J.Y., Le Coz, J.R., 1977. Trypsine, amylase et protéines du zooplancton: dosage automatique et manuel. J. Exp. Mar. Biol. Ecol. 29, 279-289.

Sokolova, I.M., Evans, S., Hughes, F.M., 2004. Cadmium-induced apoptosis in oyster hemocytes involves disturbance of cellular energy balance but no mitochondrial permeability transition. J. Exp. Biol. 207, 3369-3380.

Sures, B., 2008. Environmental parasitology. Interactions between parasites and pollutants in the aquatic environment. Parasite. 15 (3), 434-438.

Tanguy, A., Boutet, I., Riso, R., Boudry, P., Auffret, M., Moraga, D., 2003. Metallothionein genes in the European flat oyster Ostrea edulis: a potential ecological tool for environmental monitoring?. Mar. Ecol. Prog. Ser. 257, 87-97.

Tillmann, U., Alpermann, T., John, U., Cembella, A., 2008. Allelochemical interactions and short-term effects of the dinoflagellate Alexandrium on selected photoautotrophic and heterotrophic protists. Harmful Algae. 7, 52-64. 
Tran, D., Fournier, E., Durrieu, G., Massabuau, J.C., 2003a. Copper detection in the Asiatic clam Corbicula fluminea: optimum valve closure response. Aquat. Toxicol. 66, 333343.

Tran, D., Ciret, P., Ciutat, A., Durrieu, G., Massabuau, J.-C., 2003b. Estimation of potential and limits of bivalve closure response to detect contaminants: application to cadmium. Environ. Toxicol. Chem. 22, 116-122.

World Health Organization. 2006. Guidelines for Drinking-water Quality: First Addendum to Third Edition, Volume 1, Recommendations. World Health Organization. http://www.who.int/water_sanitation_health/dwq/gdwq3/en/.

Zaldibar, B., Cancio, I., Marigomez, I., 2007. Reversible alterations in epithelial cell turnover in digestive gland of winkles (Littorina littorea) exposed to cadmium and their implications for biomarker measurements. Aquat. Toxicol. 81, 183-196.

Zaldibar, B., Cancio, I., Soto, M., Marigomez, I., 2008. Changes in cell-type composition in digestive gland of slugs and its influence in biomarkers following transplantation between a relatively unpolluted and a chronically metal-polluted site. Environ. Pollut. 156, 367-379.

Zorita, I., Ortiz-Zarragoitia, M., Soto, M., Cajaraville, M.P., 2006. Biomarkers in mussels from a copper site gradient (Visnes, Norway): An integrated biochemical, histochemical and histological study. Aquat. Toxicol. 78, 109-116. 


\section{Figure captions}

766 Fig. 1. PST content (mean of 3 pools of 10 oysters, as $\mu$ g STX eq. $100 \mathrm{~g}^{-1}$ of tissue wet weight, $\pm \mathrm{CI}$ ) in digestive gland of oysters exposed to A. minutum and A. minutum $+\mathrm{Cd}-\mathrm{Cu}$.

Fig. 2. Cadmium (A) and copper (B) contents (mean of 3 pools of 10 oysters, as $\mu \mathrm{g} \mathrm{g}^{-1}$ of

770 tissue dry weight, $\pm \mathrm{CI}$ ) in digestive gland of oysters exposed to both microalgae (T. lutea and A. minutum) and metals (Cd-Cu).

Fig. 3. (A) Total hemocyte concentration (cells $\mathrm{ml}^{-1}$ ), (B) percentage of dead hemocytes, (C) phagocytosis rate, (D) ROS production in granulocytes (AU), (E) specific activity of phenoloxidase (PO) in hemocytes, (F) specific activity of phenoloxidase (PO) in plasma. Means of 15 individual oysters, \pm CI. * Statistically significant differences according to Cd$\mathrm{Cu}$ exposure, $A$. minutum exposure, and interaction, respectively (two-way ANOVA ; * : $\mathrm{p}<0.05 ; *^{* *}: \mathrm{p}<0.01 ; * * *: \mathrm{p}<0.001$ ). Lower-case letters (a, b and c) indicate homogeneous 780 groups (Tukey’s HSD test). AU: arbitrary unit. 
Table 1. Neutral lipid class contents (expressed as $\mathrm{mg} \mathrm{g}^{-1}$ of tissue wet weight, $\pm \mathrm{CI}$, means of 3 pools of 10 oysters each) in oyster digestive glands according to exposure conditions. This table also indicates the results of the two-way ANOVAs testing by Cd-Cu exposure (M) and dietary effects (D). Lower-case letters (a, b and c) indicate homogeneous groups (Tukey's HSD test).

\begin{tabular}{|c|c|c|c|c|c|c|c|}
\hline \multirow{3}{*}{$\begin{array}{c}\text { metals (M) } \\
\operatorname{diet}(\mathrm{D})\end{array}$} & \multicolumn{4}{|c|}{ Mean $\pm \mathrm{Cl}(\mathrm{n}=3)$} & \multicolumn{3}{|c|}{ Two-way ANOVA } \\
\hline & \multicolumn{2}{|c|}{ control } & \multicolumn{2}{|c|}{ exposed } & \multirow{2}{*}{$M$} & \multirow{2}{*}{$\mathrm{D}$} & \multirow{2}{*}{$M / D$} \\
\hline & A. minutum & T. lutea & A. minutum & T. lutea & & & \\
\hline monoacylglycerols (MAG) & $0.09 \pm 0.03(\mathrm{a})$ & $0.27 \pm 0.02(b)$ & $0.18 \pm 0.06$ (c) & $0.2 \pm 0.04$ (c) & NS & $* *$ & $* *$ \\
\hline diacylglycerols (DAG) & $0.07 \pm 0.04(\mathrm{a})$ & $0.15 \pm 0.01(b)$ & $0.16 \pm 0.01(b)$ & $0.21 \pm 0.03(\mathrm{c})$ & $* *$ & $* *$ & NS \\
\hline sterols & $1.69 \pm 0.05(a)$ & $1.57 \pm 0.06(b)$ & $1.16 \pm 0.09$ (c) & $1.25 \pm 0.11$ (c) & $* * *$ & NS & $*$ \\
\hline free fatty acids (FFA) & $0.29 \pm 0.16(a)$ & $0.31 \pm 0.05(\mathrm{a})$ & $0.37 \pm 0.29(a)$ & $0.25 \pm 0.29(a)$ & NS & NS & NS \\
\hline triacylglycerols & $6.07 \pm 0.61(a)$ & $6.74 \pm 1.84(\mathrm{a})$ & $7.2 \pm 1.14(\mathrm{a})$ & $5.46 \pm 2.8(a)$ & NS & NS & NS \\
\hline ether glycerides & $1.04 \pm 0.15(a)$ & $1.89 \pm 0.3(b)$ & $1.35 \pm 0.12(\mathrm{a})$ & $1.18 \pm 0.44(\mathrm{a})$ & NS & $*$ & $* *$ \\
\hline sterol esters & $0.33 \pm 0.06(a)$ & $0.3 \pm 0.1(\mathrm{a})$ & $0.3 \pm 0.07(a)$ & $0.26 \pm 0.11(a)$ & NS & NS & NS \\
\hline Total & $9.58 \pm 0.62(a)$ & $11.22 \pm 2.15(a)$ & $10.72 \pm 0.88(a)$ & $8.8 \pm 2.94(\mathrm{a})$ & NS & NS & NS \\
\hline
\end{tabular}

Table 2. Phospholipid class contents (expressed as $\mathrm{mg} \mathrm{g}^{-1}$ of tissue wet weight, $\pm \mathrm{CI}$, means of 3 pools of 10 oysters each) in oyster digestive glands according to exposure conditions. This table also indicates the results of the two-way ANOVAs testing by Cd-Cu exposure (M) and dietary effects (D). Lower-case letters ( $a$ and $b$ ) indicate homogeneous groups (Tukey’s HSD test).

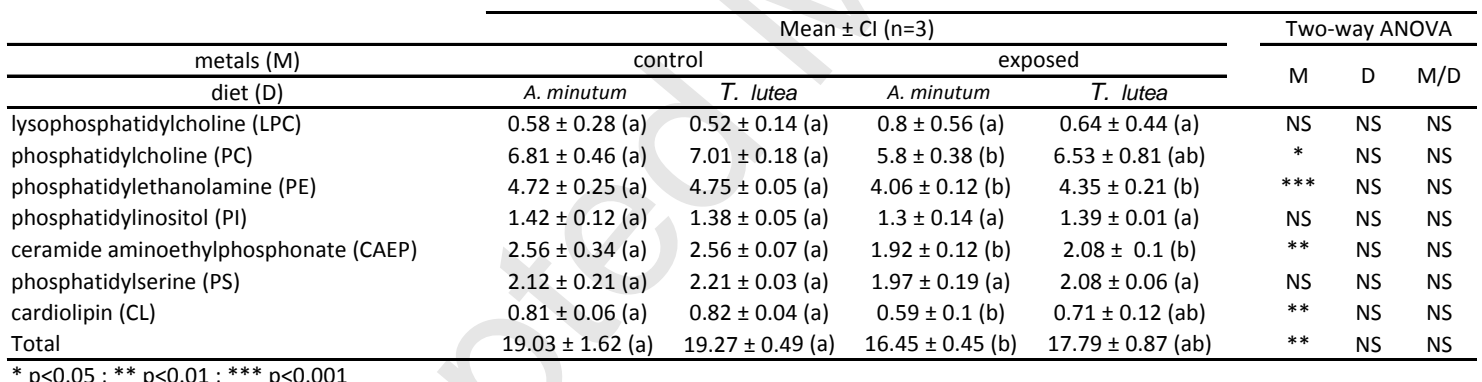

Table 3. Effects of metal exposure and microalgal exposure on oyster hemocyte and plasma variables $(n=15)$, tested by two-way ANOVA.

\begin{tabular}{cccc}
\hline variables & metal exposure & diet & interaction \\
\hline hemocytes & & & \\
total hemocyte concentration & $* *$ & $*$ & $* *$ \\
$\%$ of dead hemocytes & $* *$ & NS & NS \\
phagocytosis rate (\%) & $* * *$ & $*$ & NS \\
ROS production in granulocytes & $* *$ & NS & NS \\
ROS production in hyalinocytes & $* * *$ & NS & NS \\
specific activity of PO in hemocytes & $*$ & NS & NS \\
plasma & & & \\
specific activity of PO in plasma & NS & $*$ & NS \\
\hline
\end{tabular}

$* \mathrm{p}<0.05 ;{ }^{* *} \mathrm{p}<0.01 ;{ }^{* * *} \mathrm{p}<0.001$

$\mathrm{PO}=$ phenoloxidase 
800

801

802

803

804

805

806

\section{Research highlights:}

- $\quad$ oysters, C. gigas, were exposed to both metals and PST-producer A. minutum

- oysters exposed to metals accumulated about thirty-six times less PSTs

- $\quad$ exposure to both metals and A. minutum induced antagonistic or synergetic effects 
806

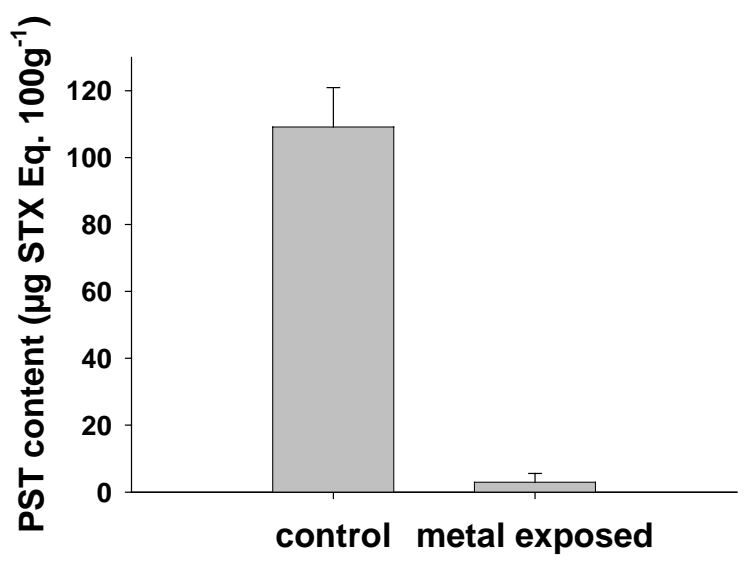

807

Fig. 1.

808 
808
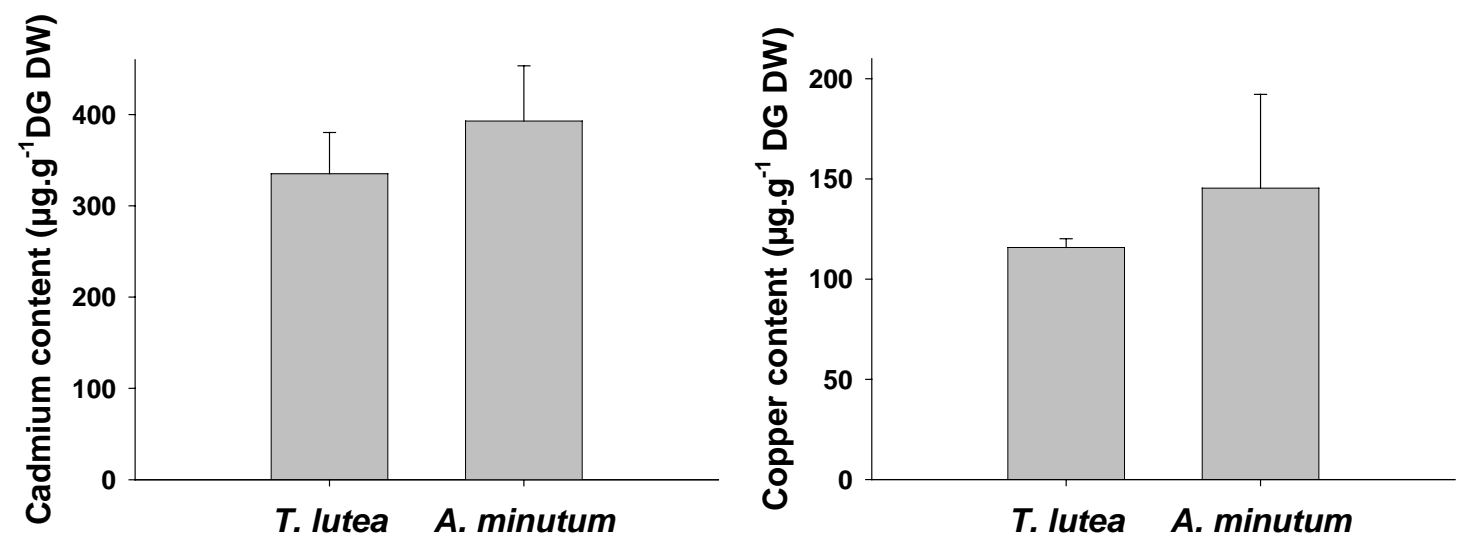

809 Fig. 2.

810 

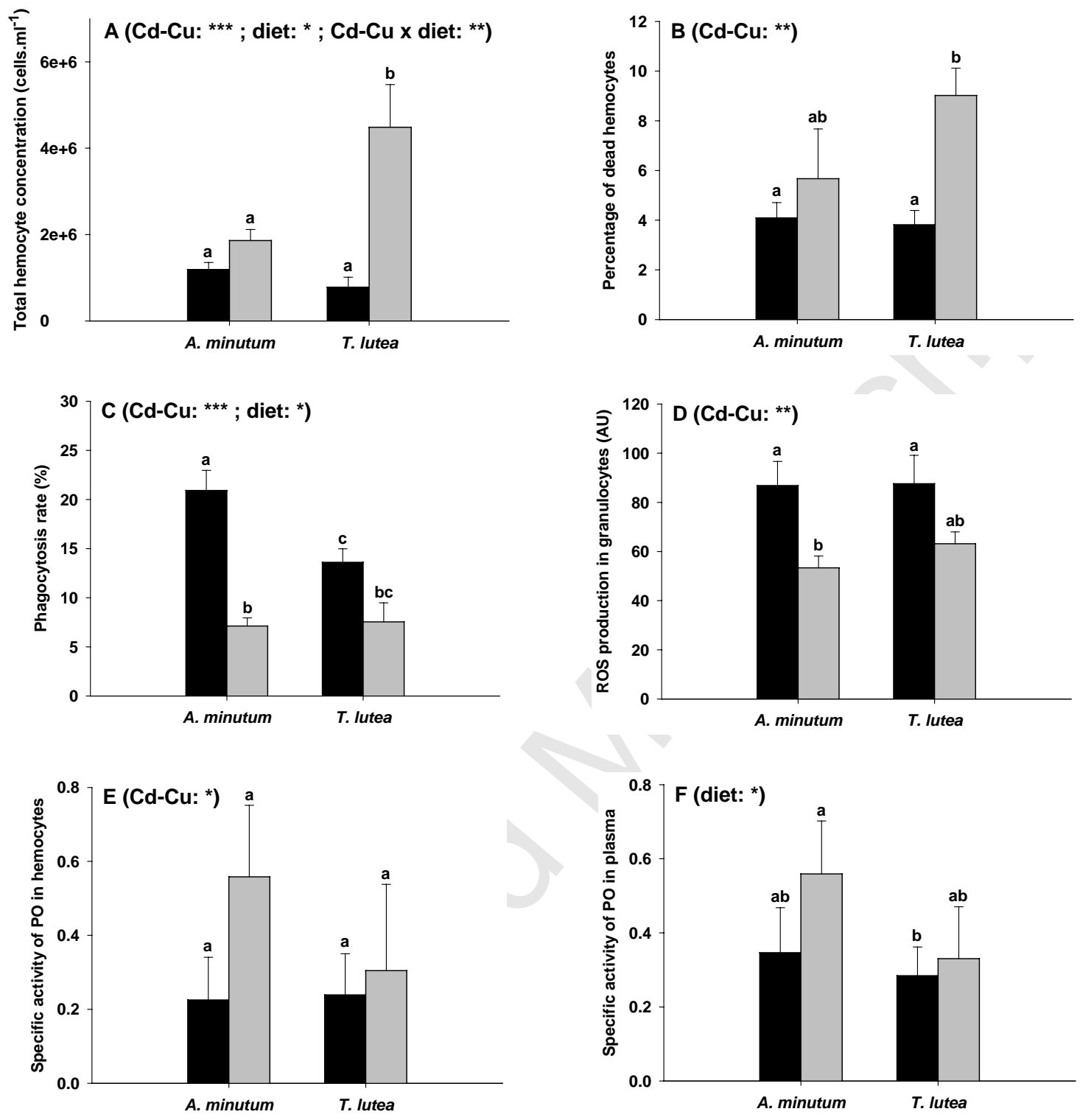

810

\section{$\mathrm{Cd}-\mathrm{Cu}$}

811

812

Fig. 3.

813

814 